\title{
POTENTIAL APPLICATION OF LYOPHILIZATION IN COMMERCIAL USE OF BACTERIOPHAGE PREPARATIONS IN VETERINARY MEDICINE
}

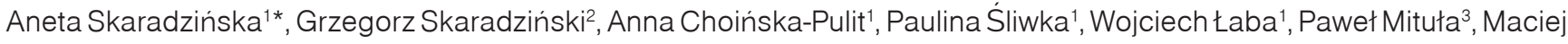 \\ Żaczek ${ }^{4}$, Beata Weber-Dąbrowska ${ }^{4}$ \\ 'Department of Biotechnology and Food Microbiology, ${ }^{2}$ Department of Fermentation and Cereal Technology, Faculty of Biotechnology \\ and Food Science, Wroclaw University of Environmental and Life Sciences; Chełmońskiego 37,51-630 Wrocław, ${ }^{3}$ Institute of Environmental \\ Engineering, Faculty of Environmental Engineering and Geodesy, Wroclaw University of Environmental and Life Sciences, Grunwaldzki \\ Sq. 24, 50-363, Wrocław, ${ }^{4}$ Laboratory of Bacteriophages, Ludwik Hirszfeld Institute of Immunology and Experimental Therapy (IIET), Polish \\ Academy of Sciences; R. Weigla 12, 53-114 Wrocław, Poland
}

*Corresponding author, E-mail: aneta.skaradzinska@upwr.edu.pl

\begin{abstract}
Microbial contamination in livestock, resulting in foodborne illnesses, poses a serious problemforveterinarymedicine. Rapidly growing number of antibiotic-resistant bacterial strains triggers increased interest in phage therapy, which has already been tested against zoonotic pathogens in animals.

The aim of the study was to investigate the potential application of lyophilization process in commercial processing of phages. We lyophilized three phages active against common animal pathogens Escherichia coli, Salmonella sp. and Enterococcus faecalis, in the presence of three different cryoprotectants. The activity of phages was determined after 10 days, 1 month, 3 months, 6 months and 1 year storage at room temperature. All conditions of storage were established to consider practical aspects of phages processing.

Skim milk appeared to be the most effective cryoprotectant, however the obtained results varied for different phages, suggesting that efficiency of this process was phage-dependent. This in turn, may be problematic during optimization of phage lyophilization for commercial processing. Nevertheless, further commercialization of phage preparations seems to be unavoidable and the development of new methods for phage processing and storage is required.
\end{abstract}

Key words: bacteriophages; lyophilization; freeze-drying; long-term preservation of bacteriophages

\section{Introduction}

Bacteriophages (phages) have been used as antibacterial agents almost since their discovery at the beginning of the $20^{\text {th }}$ century. The discovery of penicillin and subsequently other antibiotics, accompanied by scarce knowledge regarding the nature of these viruses, caused significant limitation of phage application.

Received: 4 April 2016

Accepted for publication: 25 September 2017
Nowadays, increasing inefficiency of chemical agents in treatment and prevention of bacterial infections is the main cause of renewed interest in bacteriophages (1).

Microbial contamination of livestock, resulting in foodborne illnesses, is a serious problem for the food industry. Bovines are the main animal reservoir of enterohemorrhagic E. coli (EHEC), which is considered the major cause of hemolyticuremic syndrome (HUS) worldwide (2-4). In turn, contaminated poultry and swine are the two major reservoirs of Salmonella. Increasing multi- 
drug resistance of Salmonella enterica strains is due to use of antibiotics as growth promoters in food animal production $(5,6)$.

The rising importance of phage preparations is reflected by the increasing number of commercial products based on phages appearing on the market. Although phage therapy in humans has been practiced only as an experimental form of treatment, in the last decade, approvals for commercial use of phage products in the area of veterinary medicine and food safety have been granted increasingly often. An important advantage is the possibility of using phage preparations for reducing bacterial contamination in the entire food chain, from reducing pathogen colonization in livestock, through decontamination of raw meats, to expanding shelf life of ready products (7). Nowadays, several phage products are available on the market, including the following: (i) LMP-102TM (Listshield) produced by Intralytix Inc. (USA), which is used to control Listeria monocytogenes in ready-to-eat meat and poultry products before packaging; (ii) ECP-100TM (Ecoshield) against E. coli O157:H7 i.a. in ground beef (Intralytix Inc.) (USA); (iii) Listex, effective against $L$. monocytogenes, and (iv) SALMONELEX against Salmonella, both produced by EBI Food Safety (Netherlands); and (v) BacWash, which is in the form of two separate products targeting Salmonella and E. coli O157:H7 on animal hides prior to slaughter (Omnilytics, Inc) (USA) (8). As the further commercialization of phage preparations seems to be unavoidable, there is an obvious need to search for methods of phage processing and long-term storage.

The aim of our studies was to investigate the potentialapplication oflyophilization in commercial use of phage preparations as components of feed additives in veterinary medicine. We compared the activity of three bacteriophages from three different groups of phages related to animal infections (specific to E. coli, Salmonella sp. and Enterococcus sp.), lyophilized with different cryoprotectants and stored for one year. In our studies we used bacteriophage T4 (specific to $E$. coli), which is one of the best known bacteriophages, and the two bacteriophages Salm G713 and Entc 24 with high lytic activity (specific to Salmonella sp. and Enterococcus faecalis, respectively). As the cryoprotectants we used skim milk, as it is one of the most frequently used cryoprotectants (9), and sucrose, which according to previous reports may be useful in stabilization of freeze-dried bacteriophages (10). Considering potential application of phages as components of feed additives for farm animals, we also used commercial feed additive (Skotan S.A., Poland) as a potential stabilizer of phages during lyophilization. This additive is based on the yeast Yarrowia lipolytica, the cell wall of which, like the cell walls of all the yeasts, is built from different polysaccharides. This might suggest the potential role of this yeast in phage protection during lyophilization and would be a practical solution in commercial processing of phages. The phage activity was determined after 10 days, 1 month, 3 months, 6 months and 1 year storage at room temperature (RT). Time and conditions of storage were also established taking into consideration practical processing of phages.

\section{Material and methods}

\section{Bacteriophages and bacterial strains}

Bacteriophages T4, Salm G713 and Entc 24 were obtained from the Polish Collection of Microorganisms in the Institute of Immunology and Experimental Therapy (IIET), Polish Academy of Sciences (PAS). Phages were propagated respectively with Escherichia coli B, Salmonella 7116 and Enterococcus faecalis 661 strains (IIET Bacterial Collection). Bacteriophage lysates were obtained according to the method described by Carlson and Miller 1994 (11). The titer of phages used in the experiments was: T4 $-3 \times 10^{9} \mathrm{pfu} / \mathrm{mL}$; Salm G713 - $4.50 \times 10^{9} \mathrm{pfu} / \mathrm{mL}$; Entc $24-2.5$ x $10^{10} \mathrm{pfu} / \mathrm{mL}$.

\section{Cryoprotectants}

Three cryoprotectants were used: (i) skim milk (Sigma-Aldrich, Germany) with the final concentration $10 \% \mathrm{w} / \mathrm{v}$, (ii) sucrose (SigmaAldrich, Germany) with the final concentration $17 \% \mathrm{w} / \mathrm{v}$, and (iii) commercial animal feed additive for farm animals, with great nutritional value, based on Yarrowia lipolytica yeast (Yarrowia GoodStart, Skotan S.A., Poland), with the final concentration $10 \% \mathrm{w} / \mathrm{v}$. The feed additive was disrupted by sonification ( $5 \mathrm{~min}$, ice cooling, $\mathrm{P}=$ $70 \mathrm{~W}, \mathrm{f}=20 \mathrm{kHz}$ (Sonoplus HD 2200, Bandelin electronic GmbH \& Co. KG, Germany). 
Twice concentrated solutions of skim milk and yeast feed additive were sterilized by autoclaving $\left(117^{\circ} \mathrm{C}, 0.8 \mathrm{~atm}, 20 \mathrm{~min}\right)$. To confirm the efficiency of this sterilization process, we prepared $72 \mathrm{~h}$ cultures of the Bacillus cereus (ATCC 14579) and Bacillus subtilis (ATCC 6633) in LB and sterilized it under the above conditions. Then we induced the germination of the spores with a heat shock $\left(80^{\circ} \mathrm{C}, 20 \mathrm{~min}.\right)$ and determined the number of bacteria with plate count method. For both bacterial species we observed $100 \%$ inactivation of bacteria compared to control cultures, which were not sterilized.

Twice concentrated solution of sucrose was sterilized by filtration (membrane pore size: 0.22 $\mu \mathrm{m})$. Phage lysates were mixed with cryoprotectants $(1: 1 \mathrm{v} / \mathrm{v})$ before lyophilization.

\section{Lyophilization}

The phage lysate was mixed with protective agents $(1: 1 \mathrm{v} / \mathrm{v})$. The samples of $1 \mathrm{~mL}$ in vials of $2 \mathrm{~cm}$ diameter were placed on the shelf in the Labconco Triad freeze-drier and prefrozen to -36 ${ }^{\circ} \mathrm{C}$ at $0.5{ }^{\circ} \mathrm{C} / \mathrm{min}$. The process of freeze-drying was carried out at $-36{ }^{\circ} \mathrm{C}, 0.20$ mbar for 19 hours, followed by a temperature shift to $-10{ }^{\circ} \mathrm{C}$ and pressure 0.18 mbar for 1.5 hours and finally +5 ${ }^{\circ} \mathrm{C}, 0.16$ mbar for 4 hours. The vials were sealed under vacuum and stored.

\section{Storage of the samples}

Samples were stored at RT and the temperature of the storage was controlled twice a day each day of the experiment. Total storage time of the samples was 1 year as the term of validity for the tested feed additive was 12 months.

\section{Stability tests of the lyophilized bacteriophages}

After 10 days, 1 month, 3 months, 6 months and 1 year, the lyophilized samples were hydrated by the addition of $1 \mathrm{~mL}$ of sterile, $0.9 \% \mathrm{NaCl}$ solution. Then, the samples were incubated at $37{ }^{\circ} \mathrm{C}$ with shaking $(200 \mathrm{rpm})$ for 1 hour. Titer of phages was determined with routine test dilution (RTD) and subsequently with the double-layer agar plates method (12). The stability tests for each variant were performed in triplicate.

\section{Statistical analysis}

Two-way ANOVA was performed for the stability test results and significant differences were determined according to Duncan's test, at $\mathrm{P}=0.05$. Interaction graphs were plotted and standard error bars were provided to data points (Statistica 10, StatSoft).

\section{Results}

The following samples were prepared: (i) bacteriophage lysate stored at $4^{\circ} \mathrm{C}$; (ii) bacteriophage lysate stored at RT; (iii) lyophilized bacteriophage lysate with no cryoprotectants stored at RT; (ivvi) lyophilized bacteriophage lysates with different cryoprotectants stored at RT.

Number of viable phages T4, Salm G713 and Entc 24 per $\mathrm{mL}$ stored for 10 days, 1 month, 3 months, 6 months and 1 year of storage at RT are presented in Tables 1-3.

\section{Discussion}

Lyophilization is commonly used for immobilization of different biological particles in industrial applications, as it facilitates transport of the product and reduces the space needed for its storage. Although lyophilization is considered one of the most effective methods of stabilization of various biological particles, in the context of commercial phage usage its application might be rather limited.

In our studies, phages retained the highest activity when stored at $4{ }^{\circ} \mathrm{C}$ (as lysates); however, the storage of the product at this temperature is not convenient for the consumer, especially in farms. A slight decrease in phage activity (compared to the initial preparation and to the preparation stored at $4{ }^{\circ} \mathrm{C}$ ) was observed for phage preparations stored at RT, suggesting that this temperature of storage might also be applied. The drying method was not satisfactory, as phages stored in freeze-dried form significantly lost their titer compared to phages stored at $4{ }^{\circ} \mathrm{C}$ and $\mathrm{RT}$. It is noticeable that the obtained results differed for different phages.

These results confirm previous observations of Clark (1962), who compared different methods of storage of phages specific to nine different bacterial species. He showed that phage storage in broth 
Table 1: The number of viable phages T4 per ml during storage of lyophilized products. The initial phage titer was $9.48 \log \mathrm{pfu} / \mathrm{mL}\left(3 \times 10^{9} \mathrm{pfu} / \mathrm{mL}\right)$

\begin{tabular}{|c|c|c|c|c|c|}
\hline $\mathrm{T} 4$ & $\begin{array}{c}10 \text { days } \\
(\log \mathrm{pfu} / \mathrm{mL})\end{array}$ & $\begin{array}{c}1 \text { month } \\
(\log \mathrm{pfu} / \mathrm{mL})\end{array}$ & $\begin{array}{l}3 \text { months }(\log \\
\text { pfu } / \mathrm{mL})\end{array}$ & $\begin{array}{l}6 \text { months (log } \\
\text { pfu/mL) }\end{array}$ & $\begin{array}{c}1 \text { year } \\
(\log \mathrm{pfu} / \mathrm{mL})\end{array}$ \\
\hline Phage lysate $\left(4^{\circ} \mathrm{C}\right)$ & $9.73^{a}$ & $9.91^{\mathrm{a}}$ & $9.86^{a}$ & $9.87^{a}$ & $9.58^{a}$ \\
\hline Phage lysate (RT) & $8.22^{\mathrm{b}}$ & $9.91^{\mathrm{a}}$ & $9.75^{\mathrm{a}}$ & $9.43^{\mathrm{a}}$ & $8.89^{\mathrm{i}}$ \\
\hline Lyophilized phage lysate & $9.77^{\mathrm{a}}$ & $8.20^{\mathrm{b}}$ & $5.16^{\text {e.f }}$ & $3.02^{\mathrm{h}}$ & ud. \\
\hline $\begin{array}{l}\text { Phage lysate lyophilized } \\
\text { with skim milk }\end{array}$ & $6.21^{\mathrm{c.d}}$ & $5.96^{\mathrm{c.d}}$ & $5.68^{\mathrm{c.f}}$ & $4.90^{e}$ & $4.26^{j}$ \\
\hline $\begin{array}{l}\text { Phage lysate lyophilized } \\
\text { with sucrose }\end{array}$ & $5.23^{e . f}$ & $5.99^{\text {c.d }}$ & $5.09^{e}$ & $7.43^{\mathrm{g}}$ & $6.18^{\mathrm{c.d}}$ \\
\hline $\begin{array}{l}\text { Phage lysate lyophilized } \\
\text { with yeast feed additive }\end{array}$ & $7.73^{\mathrm{b} . \mathrm{g}}$ & $7.65^{\mathrm{b} . \mathrm{g}}$ & $6.55^{d}$ & $3.41^{\mathrm{h}}$ & ud. \\
\hline
\end{tabular}

The same superscript letters designate homogenous groups.

ud. - undetected

Table 2: The number of viable phages Salm 713 per $\mathrm{ml}$ during storage of lyophilized products. The initial phage titer was $4.50 \times 10^{9} \mathrm{pfu} / \mathrm{mL}(9.65 \log \mathrm{pfu} / / \mathrm{mL})$

\begin{tabular}{|c|c|c|c|c|c|}
\hline Salm 713 & $\begin{array}{c}10 \text { days } \\
(\log \mathrm{pfu} / \mathrm{mL})\end{array}$ & $\begin{array}{c}1 \mathrm{month} \\
(\log \mathrm{pfu} / \mathrm{mL})\end{array}$ & $\begin{array}{l}3 \text { months }(\log \\
\text { pfu } / \mathrm{mL})\end{array}$ & $\begin{array}{l}6 \text { months }(\log \\
\text { pfu } / \mathrm{mL})\end{array}$ & $\begin{array}{c}1 \text { year } \\
(\log \mathrm{pfu} / \mathrm{mL})\end{array}$ \\
\hline Phage lysate $\left(4^{\circ} \mathrm{C}\right)$ & $9.73^{\mathrm{a}}$ & $9.80^{\mathrm{a}}$ & $9.70^{\mathrm{a}}$ & $9.65^{a . b}$ & $9.17^{\text {b.d }}$ \\
\hline Phage lysate (RT) & $9.65^{a . b}$ & $9.60^{a . b}$ & $9.51^{a . b}$ & $9.48^{a . b}$ & $8.76^{\mathrm{c.d}}$ \\
\hline Lyophilized phage lysate & $8.79^{\mathrm{c} . \mathrm{d}}$ & 8.37 c.f.g & $7.98^{\mathrm{f} . j}$ & $6.89^{1}$ & $5.00^{\mathrm{i}}$ \\
\hline $\begin{array}{l}\text { Phage lysate lyophilized- } \\
\text { with skim milk }\end{array}$ & $8.83^{\mathrm{c.d}}$ & $8.52^{\mathrm{c.g}}$ & $8.34^{\text {c.f.g }}$ & $8.15^{\text {f.g.j }}$ & $7.31^{\mathrm{k} .1}$ \\
\hline $\begin{array}{l}\text { Phage lysate lyophilized } \\
\text { with sucrose }\end{array}$ & $6.27^{\mathrm{e}}$ & $4.60^{\text {h.i }}$ & $6.35^{\mathrm{e}}$ & $4.69^{h . i}$ & $5.63^{\mathrm{m}}$ \\
\hline $\begin{array}{l}\text { Phage lysate lyophilized } \\
\text { with yeast feed additive }\end{array}$ & $8.27^{\mathrm{f.g}}$ & $8.14^{\text {f.g.j }}$ & $7.74^{\mathrm{j} \cdot \mathrm{k}}$ & $6.32^{\mathrm{e}}$ & $4.29^{h}$ \\
\hline
\end{tabular}

The same superscript letters designate homogenous groups

Table 3: The number of viable phages Entc 24 per $\mathrm{ml}$ during storage of lyophilized products. The initial phage titer was $2.5 \times 10^{10} \mathrm{pfu} / \mathrm{mL}(10.40 \log \mathrm{pfu} / \mathrm{mL})$

\begin{tabular}{|c|c|c|c|c|c|}
\hline Entc 24 & $\begin{array}{c}10 \text { days } \\
(\log \mathrm{pfu} / \mathrm{mL})\end{array}$ & $\begin{array}{c}1 \mathrm{month} \\
(\log \mathrm{pfu} / \mathrm{mL})\end{array}$ & $\begin{array}{l}3 \text { months (log } \\
\mathrm{pfu} / \mathrm{mL})\end{array}$ & $\begin{array}{l}6 \text { months }(\log \\
\mathrm{pfu} / \mathrm{mL})\end{array}$ & $\begin{array}{c}1 \text { year } \\
(\log \mathrm{pfu} / \mathrm{mL})\end{array}$ \\
\hline Phage lysate $\left(4^{\circ} \mathrm{C}\right)$ & $10.22^{a . b}$ & $10.27^{\text {b.h }}$ & $10.38^{\mathrm{h}}$ & $9.75^{\text {c.e }}$ & $9.63^{e . f}$ \\
\hline Phage lysate (RT) & $10.10^{\text {a.c.d }}$ & $9.99^{d}$ & $9.85^{c}$ & $9.27^{\mathrm{g}}$ & $7.88^{\mathrm{m}}$ \\
\hline Lyophilized phage lysate & $9.71^{\text {c.e }}$ & $9.50^{\mathrm{f}}$ & $9.62^{e . f}$ & $8.49^{j}$ & $7.83^{\mathrm{m}}$ \\
\hline $\begin{array}{l}\text { Phage lysate lyophilized } \\
\text { with skim milk }\end{array}$ & $9.52^{\mathrm{f}}$ & $9.54^{f}$ & $9.79^{c}$ & $9.18^{\mathrm{g}}$ & $8.72^{\mathrm{k}}$ \\
\hline $\begin{array}{l}\text { Phage lysate lyophilized } \\
\text { with sucrose }\end{array}$ & $9.50^{f}$ & $9.63^{e . f}$ & $9.82^{c}$ & $8.9^{\text {i.k }}$ & $8.64^{\mathrm{k} .1}$ \\
\hline $\begin{array}{l}\text { Phage lysate lyophilized } \\
\text { with yeast feed additive }\end{array}$ & $9.18^{g}$ & $8.93^{\mathrm{i}}$ & $9.19^{g}$ & $8.51^{\mathrm{j} .1}$ & $7.20^{\mathrm{n}}$ \\
\hline
\end{tabular}

The same superscript letters designate homogenous groups 
at $4{ }^{\circ} \mathrm{C}$ was the most efficient method for phage preservation, while freeze-drying (with skim milk as a cryoprotectant) was damaging for all studied viruses. Considering both prestorage treatment and the storage ( 2 years, $4{ }^{\circ} \mathrm{C}$ ), of twenty phages, only two showed the best recovery in lyophilized form (13).

We showed that skim milk and sucrose may be potential cryoprotectants in the lyophilization process. However, optimization of the method in order to increase phage survival is required. This applies in particular to lyophilization with sucrose, as the results of the studies were particularly inconsistent. Yeast feed additive was the least efficient cryoprotectant, but it is necessary to emphasize that the results were significantly different for different phages. Radical differences were observed in the case of phages lyophilized with no cryoprotectant. Phage Entc 24 specific to Enterococcus faecalis retained its activity compared to phage stored at RT after 12 months, while phage T4 specific to E. coli completely lost its activity when stored in this form. Phage Salm G713 specific to Salmonella sp. showed intermediate loss of its activity.

In studies presented by Dini and de Urraza (2013), phages lyophilized with skim milk lost $1.2 \log \mathrm{pfu} / \mathrm{mL}$ after the process $(6 \%$ phage survival) (14). This is also in accordance with the aforementioned publication of Clark (1962), who observed that the survival of two coliphages lyophilized with skim milk was in the range $25 \%$ - less than $1 \%$.

Although disaccharides are expected to increase the protection of the particles during lyophilization (15), application of sucrose as the cryoprotectant of phages gives ambiguous results. Data regarding usage of sucrose as a cryoprotectant are variable and show that in each case, optimization of the method is needed. In studies presented by Dini and Urraza (2013) disaccharides did not improve the stability of phages during freeze-drying compared to PBS. It is worth mentioning that the addition of $0.3 \mathrm{M}$ sucrose provided a protective effect on the lyophilized phage during storage (120 days) compared to that obtained immediately after lyophilization. Phages lyophilized in SM buffer showed significantly increased stability compared to PBS (phage survival range 1-15\% after lyophilization).The addition of $0.1 \mathrm{M}$ sucrose significantly increased the number of active phages after lyophilization compared with the number of phages lyophilized in SM buffer alone.
The stability was also improved compared to skim milk. Phage preparations lyophilized in SM buffer with $0.1 \mathrm{M}$ sucrose also showed great stability, retaining almost full phage activity during 120 days of storage compared to the phage titer immediately after lyophilization. The addition of higher sucrose concentrations $(0.3 \mathrm{M} ; 0.5 \mathrm{M})$ was detrimental for phage stability compared to samples lyophilized without sucrose (14).

Dini and de Urraza (2013) analyzed each step of the freeze-drying process (PBS with $0.5 \mathrm{M}$ sucrose), showing that the main phage loss occurs during the drying step (decrease of $1.58 \mathrm{log} \mathrm{pfu} / \mathrm{mL}$ ). If lyophilized with $0.1 \mathrm{M}$ concentration of sucrose, phage viability was almost completely retained during the freeze-thaw step, and the observed loss of phage titer $(0.56 \log \mathrm{pfu} / \mathrm{mL})$ was attributed to the drying step. The analysis of the storage of lyophilized preparations $\left(4^{\circ} \mathrm{C}, 120\right.$ days) showed the stabilizing effect of sucrose (PBS with $0.3 \mathrm{M}$ sucrose and SM with 0.1 M sucrose) (14).

In another study, the authors optimized the lyophilization process by testing four different concentrations of trehalose and sucrose, as they seemed to be the best cryoprotectants of Staphylococcus phage ISP. The immediate decrease in titer after lyophilization varied between 0.6 and $1.4 \mathrm{log} / \mathrm{mL}$, and the best results were obtained in the case of $0.8 \mathrm{M}$ and $1.0 \mathrm{M}$ sucrose, with loss of only $0.4-0.5 \mathrm{log} / \mathrm{mL}$. During the 27 -month storage period, the activity of ISP remained stable, with variations within one $\log / \mathrm{mL}$ in all preparations, except for 0.3 M trehalose (10). Also, in studies presented by Puapermpoonsiri et al. (2010), higher loss of activity was observed for phages lyophilized with high concentrations of sucrose $(0.5 \mathrm{M})$ than with lower concentrations $(0.1 \mathrm{M})(16)$.

Also potential application of other cryoprotectants in lyophilization of phages has been studied. PEG6000 was used for stabilization of Staphylococcus aureus phage. Immediately after immobilization, phages showed a titer loss of $1.8 \mathrm{log} / \mathrm{mL}$ and $5.0 \mathrm{log} / \mathrm{mL}$ for $1 \%$ and 5\% PEG6000 concentrations respectively. Titer loss was also observed after storage for 37 months (loss of $3 \mathrm{log} / \mathrm{mL}$ for 1\% PEG6000 and $1.7 \mathrm{log} / \mathrm{mL}$ of the titer for 5\% PEG6000) (10). These observations were also confirmed by Puapermpoonsiri et al. (2010), who showed that PEG6000 as a cryoprotectant at concentrations of $1 \%$ and $5 \%$ was detrimental for phage specific to Staphylococcus aureus but also for phage specific 
to Pseudomonas aeruginosa (16). The same phages lyophilized in SM medium with or without gelatin began to lose their activity after the 30th day of storage. Also glycine and polyvinylpyrrolidone (PVP) were detrimental for phages. Glycine caused their inactivation immediately after lyophilization and PVP inactivated phages completely at both concentrations (1\% and 5\%) even before lyophilization (10). Also mannitol at a concentration $0.1 \mathrm{M}$ caused total inactivation of phages after lyophilization. At concentration of 0.5 $\mathrm{M}$, a $4 \mathrm{log} / \mathrm{mL}$ decrease in phage titer was observed (10). Alfadhel et al. (2011) used a lyophilized viscous solution of hydroxypropyl methylcellulose (HPMC) in concentration $1-2 \%(\mathrm{w} / \mathrm{v})$ with and without addition of $1 \%(\mathrm{w} / \mathrm{v})$ mannitol to prepare inserts for nasal administration of phage against Staphylococcus aureus. Phage preparations in HPMC/mannitol gel formulations were lyophilized, which resulted in $90 \%$ loss of phage titer, but still $10^{8} \mathrm{pfu} / \mathrm{mL}\left(1 \mathrm{log} / \mathrm{mL}\right.$ decrease from $\left.10^{9} \mathrm{pfu} / \mathrm{mL}\right)$. After 1-12 months of storage at $4{ }^{\circ} \mathrm{C}$, lytic activity of phages decreased 10-1000 fold (from $10^{8} \mathrm{pfu} /$ $\mathrm{mL}$ on day 1 to around $10^{7}, 10^{6}, 10^{5} \mathrm{pfu} / \mathrm{mL}$ after 1, 2 and 5 months respectively), which still was a therapeutic dose (17).

Although there have already been published several reports regarding the influence of the freeze drying process on activity of phages, still the knowledge on this topic may be considered scarce. The results of our studies confirmed previous observations that different phages may show different tolerance to lyophilization, which may be one of the most important obstacles in optimization of the process. Even though freeze drying in general seems to be detrimental for phages, optimization of the method may allow improvement of phage survival, which may contribute to its practical usage. It is worth noting that application of lyophilization may not be limited to phage storage but also may precede (18) or follow (19) the process of phage encapsulation. Although encapsulation methods also need to be optimized, they are necessary for improved survival of phages in animals' digestive systems, as phages applied orally are often destroyed in low stomach $\mathrm{pH}$.

Phage potential in prevention and treatment of farm animal bacterial infections has been proved. According to several reports, phages were successfully applied against $E$. coli in calves, pigs, lams and poultry, against Campylobacter jejuni in chicken and against Salmonella in pigs (20-22). It was shown that bacteriophages biocontrol of $S$. enterica in dried pet food is effective and technically feasible (23). These promising results translate into a tendency toward commercialization of phage products in the fields of agriculture and veterinary medicine. Nonetheless, as phage application seems to be inevitable, research regarding biology of these viruses must be combined with development of technological processes associated with their processing.

\section{Conclusion}

Lyophilization is one of the most commonly used methods for stabilization of biological particles, however its application for bacteriophages might be rather limited. Our studies confirmed previous observations, that efficiency of the freeze-drying process depends on the applied cryoprotectant, as well as on the type of bacteriophage. Optimization of the method generally for all bacteriophages for commercial purposes is problematic, however, it is possible for single phages. In this case, lyophilization of phages may be a good solution for preservation of phage viability in time, especially considering the convenience of dried form of the preparation in contrast to a liquid lysate. As an interest in phage application significantly grows, further studies regarding the development of new methods for phage processing and storage are required.

\section{Acknowledgments}

Ethics approval: not required

The studies were conducted within the project "The application of bacteriophages to develop preparations used in animal breeding against drug resistant bacterial infections" co-financed by the Europen Regional Development Fund, Operational Programme Innovative Economy 2007-2013 grant (UDA-POIG.01.04.00-24-133/11-00) with Skotan Inc. as a beneficiary of the project.

Project supported by Wroclaw Centre of Biotechnology, programme The Leading National Research Centre (KNOW) for years 2014-2018.

We thank Mr. Richard Ashcroft, for his help in preparation of the manuscript. 


\section{References}

1. Nobrega FL, Costa AR, Kluskens LD, Azeredo J. Revisiting phage therapy: new applications for old resources. Trends Microbiol 2015; 23: 185-91.

2. Dini C, Islan GA, de Urraza PJ, Castro GR. Novel biopolymer matrices for microencapsulation of phages: enhanced protection against acidity and protease activity. Macromol Biosci 2015; 12: 1200-8.

3. Johnson S, Taylor CM. What's new in haemolytic uraemic syndrome? Eur J Pediatr 2008; 167: 965-71.

4. Rivero MA, Padola NL, Etcheverría AI, Parma AE. [Enterohemorrhagic Escherichia coli and hemolytic-uremic syndrome in Argentina]. Medicina (B. Aires) 2004; 64: 352-6.

5. Boerlin P. Implications of antimicrobial agents as therapeutics and growth promoters in food animal production. In: Sabour PM, Griffiths $\mathrm{M}$, eds. Bacteriophages in the control of food and waterborne pathogens. Washington : ASM Press, 2010: 1-9.

6. Sulakvelidze A, Alavidze Z, Morris JG. Bacteriophage therapy. Antimicrob Agents Chemother 2001; 45: 649-59.

7. Sillankorva SM, Oliveira H, Azeredo J. Bacteriophages and their role in food safety. Int $\mathrm{J}$ Microbiol 2012; 2012: e863945 (13 pp.). https://www. hindawi.com/journals/ijmicro/2012/863945/

8. Ly-Chatain $\mathrm{MH}$. The factors affecting effectiveness of treatment in phages therapy. Front Microbiol 2014; 5: e51 (7 pp.). https://www.frontiersin.org/articles/10.3389/fmicb.2014.00051/full

9. Hubálek Z. Protectants used in the cryopreservation of microorganisms. Cryobiology 2003; 46: 205-29.

10. Merabishvili M, Vervaet C, Pirnay JP, et al. Stability of Staphylococcus aureus phage ISP after freeze-drying (lyophilization). PLoS One 2013; 8(7): e68797 (7 pp.). http://journals.plos.org/plosone/ article $/$ file? id $=10.1371 /$ journal. pone $.0068797 \&$ type $=$ printable

11. Carlson K, Miller ES. Working with T4. In: Molecular biology of bacteriophage T4 Washington: American Society for Microbiology Press, 1994: 421-26.
12. Adams MH. The bacteriophages. New York: Interscience Publishers, 1959: 27-30.

13. Clark WA. Comparison of several methods for preserving bacteriophages. Appl Microbiol 1962; 10: 466-71.

14. Dini C, de Urraza PJ. Effect of buffer systems and disaccharides concentration on Podoviridae coliphage stability during freeze drying and storage. Cryobiology 2013; 66: 339-42.

15. Bedu-addo FK. Understanding lyophilization formulation development. Pharm Pharmacol 2004; 28: 10-8.

16. Puapermpoonsiri U, Ford SJ, van der Walle $\mathrm{CF}$. Stabilization of bacteriophage during freeze drying. Int J Pharm 2010; 389: 168-75.

17. Alfadhel M, Puapermpoonsiri U, Ford SJ, McInnes FJ, van der Walle CF. Lyophilized inserts for nasal administration harboring bacteriophage selective for Staphylococcus aureus: in vitro evaluation. Int J Pharm 2011; 416: 280-7. doi:10.1016/j.ijpharm.2011.07.006

18. Balcão VM, Azevedo AF, Castro LM, et al. Design of a lipid nanovesicle system encapsulating bacteriophages integrated in a multiple emulsion formulation: a proof-of-concept. In: NSTI-Nanotech. Nanotechnology 2010: bio sensors, instruments, medical, environment and energy. Vol. 3. Boca Raton: CRC Press, 2010: Chapter 7, 459-62. http:/ / www.nsti.org/procs/Nanotech2010v3/7

19. Puapermpoonsiri U, Spencer J, van der Walle CF. A freeze-dried formulation of bacteriophage encapsulated in biodegradable microspheres. Eur J Pharm Biopharm 2009; 72: 26-33.

20. Callaway TR, Edrington TS, Brabban A, et al. Evaluation of phage treatment as a strategy to reduce Salmonella populations in growing swine. Foodborne Pathog Dis 2011; 8: 261-6.

21. Monk AB, Rees CD, Barrow P, Hagens S, Harper DR. Bacteriophage applications: where are we now? Lett Appl Microbiol 2010; 51: 363-9.

22. Wall SK, Zhang J, Rostagno MH, Ebner PD Phage therapy to reduce preprocessing Salmonella infections in market-weight swine. Appl Environ Microbiol 2010; 76: 48-53.

23. Heyse S, Hanna LF, Woolston J, Sulakvelidze A, Charbonneau D. Bacteriophage cocktail for biocontrol of Salmonella in dried pet food. J Food Prot 2015; 78: 97-103. 


\title{
MOŽNOSTI UPORABE LIOFILIZACIJE V KOMERCIALNE NAMENE ZA PRIPRAVO BAKTERIOFAGOV V VETERINARSKI MEDICINI
}

\author{
A. Skaradzińska, G. Skaradziński, A. Choińska-Pulit, P.Śliwka, W. Łaba, P. Mituła, M. Żaczek, B. Weber-Dąbrowska
}

Povzetek: Mikrobiološka kontaminacija hrane v živinoreji, ki povzroča bolezni, predstavlja resen problem v veterinarski medicini. Hitro naraščajoče število bakterijskih sevov, odpornih proti antibiotikom vzbuja vedno večje zanimanje za uporabo t.i. fagoterapije, zdravljenja z bakterijskimi virusi bakteriofagi, kije bilaže preizkušena kot metoda za preprečevanje okužb priživalih. Cilj raziskave je bil proučiti potencialno uporabo postopka liofilizacije za komercialno obdelavo fagov. Liofilizirali smo tri fage, aktivne proti skupnim živalskim patogenom Escherichia coli, Salmonella sp. in Enterococcus faecalis v prisotnosti treh različnih krioprotektantov. Dejavnost fagov je bila določena po 10 dneh, 1 mesecu, 3 mesecih, 6 mesecih in 1 letu skladiščenja pri sobni temperaturi. Vzpostavljeni so bili vsi pogoji shranjevanja, z namenom upoštevanja praktičnih vidikov obdelave fagov. Posneto mleko je bilo najučinkovitejši krioprotektant, vendar so se dobljeni rezultati razlikovali pri različnih fagih, kar kaže na to, da je učinkovitost postopka odvisna od vrste faga. To bi lahko predstavljalo težavo pri optimizaciji liofilizacije fagov v komercialne namene. Kljub temu je nadaljnja komercialna priprava preparatov s fagi neizogibna in bo potrebno razvijati nove metode za obdelavo in shranjevanje fagov.

Ključne besede: bakteriofagi; liofilizacija; sušenje z zamrzovanjem; dolgoročno ohranjanje bakteriofagov 